\title{
Effectiveness of Okra Fruit (Abelmoschus esculentus) Extract Against Aggregatibacter actinomycetemcomitans (Aa) as a Bacterium that Causes Aggressive Periodontitis
}

\author{
Muhammad Luthfi', Yuliati ${ }^{1}$, Aqsa S. Oki ${ }^{1}$, Agung Sosiawan², Bella P. Cida ${ }^{3}$ \\ ${ }^{1}$ Department of Oral Biology, Faculty of Dental Medicine, Universitas Airlangga, Surabaya, Indonesia, ${ }^{2}$ Department of Dental Public Health, Faculty of Dental Medicine, \\ Universitas Airlangga, Surabaya, Indonesia, ${ }^{3}$ Faculty of Dental Medicine, Universitas Airlangga, Surabaya, Indonesia
}

\section{Abstract}

Aim: To determine that okra fruit extracts are effective in inhibiting growth and killing the Aggregatibacter actinomycetemcomitans $(A a)$ bacteria that cause aggressive periodontitis. Materials and Methods: Aa ATCC 4371 strain Y3 serotype b bacteria obtained from the Stock Research Center of the Faculty of Medicine, Airlangga University, Jawa Timur, Indonesia, were bred on the Mueller Hinton media with the inclusion criteria that identification of bacteria from the stock shows that the bacterium is $A a$, and the growth of bacteria in the Mueller Hinton media is with a number of colonies between 30-300 colony forming units (CFU)/mL. Culture media containing $\mathrm{Aa}$ bacteria were incubated for $1 \times 24 \mathrm{~h}$ at $37^{\circ} \mathrm{C}$, after it was diluted according to McFarland standard $0.5(1.5 \times 108 \mathrm{CFU} /$ $\mathrm{mL}$ ). Fresh okra fruit derived from Materia Medica was prepared for extract. Serial dilution or dilution methods of 1:2 (wt/vol) are used for the detection of minimal inhibitory concentration (MIC) and minimal bactericidal concentration (MBC). Results: One-way analysis of variance test showed a difference with significance $(P=0.000)$, whereas, Tukey honestly significant difference $($ HSD) test showed a significant difference between okra fruit extract group with positive control concentrations of 100\%, 3.125\%, and 1.565\%. Conclusion: The okra fruit extract effectively kills the $A a$ bacteria that causes aggressive periodontitis, as indicated by MIC at a concentration of $3.125 \%$ and $\mathrm{MBC}$ at a concentration of $6.25 \%$.

Keywords: Aggregatibacter Actinomycetemcomitans, Aggressive Periodontitis, Minimal Bactericidal Concentration, Minimal Inhibitory Concentration, Okra Fruit (Abelmoschus Esculentus) Extract

Received: 20-11-2018, Revised: 02-12-2019, Accepted: 05-04-2020, Published: 30-11-2020.

\section{INTRODUCTION}

Periodontitis is an inflammation that affects the supporting tissues of teeth, which is caused by microorganisms, and can cause progressive damage to the periodontal ligament, alveolar bone, and is accompanied by pocket formation. Periodontitis causes permanent tissue destruction, characterized by chronic inflammation, migration of the fused epithelium to the apical, loss of connective tissue, and loss of alveolar bone. ${ }^{[1]}$

Aggressive periodontitis (AP) is a complex disease, which is caused by microbial changes and cellular dysfunction, and is characterized by a rapid loss of attachment and bone damage to the tooth surface. ${ }^{[2]}$ The majority of

\begin{tabular}{|l|l|}
\hline \multicolumn{2}{|c|}{ Access this article online } \\
\hline Quick Response Code: & Website: \\
\hline & www.jioh.org \\
\cline { 2 - 2 } & \\
\hline
\end{tabular}

periodontal pathogens are Gram-negative anaerobes and Aggregatibacter actinomycetemcomitans $(A a)$, which has often been associated with AP. ${ }^{[3]}$ The role of this bacterium in the pathogenesis of periodontitis is due to its ability to attach to epithelial cells and produce many virulent factors such as extracellular matrix proteins, proteases, collagenase, endotoxin (LPS), bacteriocins, hemotactic inhibitors, leukotoxins, cytotoxins, toxic metabolic substances, and immunosuppressive proteins. ${ }^{[4]}$

\section{Address for correspondence: Dr. Muhammad Luthfi, Department of Oral Biology, Faculty of Dental Medicine, Universitas Airlangga, Surabaya, Indonesia E-mail:m.luthfi@fkg.unair.ac.id}

This is an open access journal, and articles are distributed under the terms of the Creative Commons Attribution-NonCommercial-ShareAlike 4.0 License, which allows others to remix, tweak, and build upon the work non-commercially, as long as appropriate credit is given and the new creations are licensed under the identical terms.

For reprints contact: reprints@medknow.com

How to cite this article: Luthfi M, Yuliati, Oki AS, Sosiawan A, Cida BP. Effectiveness of okra fruit (Abelmoschus esculentus) extract against Aggregatibacter actinomycetemcomitans $(A a)$ as a bacterium that causes aggressive periodontitis. J Int Oral Health 2020;12:556-60. 
The use of synthetic drugs is not only expensive for the treatment of a disease, but also has toxicity and adverse side effects. This type of situation causes the need to look for new drug alternatives to treat a disease. Herbal alternatives have enormous potential to develop new drugs that are very useful for treatment and are strong and effective antibacterial agents..$^{[5]}$

Abelmoschus esculentus (okra) has many benefits. This is because okra contains secondary metabolite components, such as alkaloids, terpenoids, and flavonoids. ${ }^{[6]}$ Flavonoids found in plants are known for their antibacterial effects because of their ability to reduce the permeability of bacterial cell walls. ${ }^{[7]}$

Because of the explanation of aforementioned fact, the researchers decided to prove that okra fruit extract was effective in inhibiting and killing $A a$ bacteria that cause AP. From the results of this research, it is expected to be used as a therapy for AP.

\section{Materials and Methods}

\section{Setting and design}

This was an experimental laboratory using a posttest only control group design. This study uses $A a$, ATCC 4371 strain Y3 serotype b bacteria, obtained from the Stock Research Center of the Faculty of Medicine, Airlangga University, Jawa Timur, Indonesia, with specification of ATCC 43718, which were bred on the Mueller Hinton media with the inclusion criteria that the identification of bacteria from the stock shows that the bacterium is $A a$ and the bacterial growth in the Mueller Hinton media is with a number of colonies between 30 and 300 colony forming units $(\mathrm{CFU}) / \mathrm{mL}$.

\section{Study method}

Aa ATCC 4371 strain Y3 serotype bacterial stock was inoculated in the brain heart infusion broth (BHIB) culture media. Culture media containing $A a$ bacteria was incubated for $1 \times 24 \mathrm{~h}$ at $37^{\circ} \mathrm{C}$, after which it was diluted according to McFarland standard $0.5(1.5 \times 108$ $\mathrm{CFU} / \mathrm{mL}$ ). Furthermore, the bacteria were ready to be tested.

\section{Okra fruit extract making}

Fresh okra fruit derived from Materia Medica for extract was prepared. ${ }^{[7]}$ Samples of okra fruit were cut into pieces and weighed $200 \mathrm{~g}$, then put into a jar, and $70 \%$ of ethanol was added to make the volume to $300 \mathrm{~mL}$. Maceration was carried out for $24 \mathrm{~h}$ at room temperature. After $24 \mathrm{~h}$, the solution was filtered or separated using a Buchner filter. Filtering residue was aerated, and maceration was done up to three times. The sieve 1-3 was mixed and concentrated with a rotary vacuum evaporator at $40^{\circ} \mathrm{C}$ until a concentrated extract was obtained. To obtain various concentrations, serial dilution or dilution methods of 1:2 (wt/vol) were used.

\section{Antibacterial test using the serial dilution method}

Preparation of $A a$ bacteria stored in BHIB media in an incubator at $37^{\circ} \mathrm{C}$ was obtained with a sterile Ose needle. ${ }^{[8]}$ The Mueller Hinton media was embedded by scratching. The bacteria that had been scratched on Mueller Hinton media were incubated in an incubator at $37^{\circ} \mathrm{C}$ for $1 \times 24 \mathrm{~h}$. The scratched bacteria were obtained from the Mueller Hinton media using a sterile Ose needle. It was put in the BHIB until the turbidity was the same as the McFarland 0.5 standard. Eleven sterile test tubes were prepared. Each test tube was labeled 1-9 (concentrations of $100 \%, 50 \%$, $25 \%, 12.5 \%, 6.25 \%, 3.125 \%, 1.563 \%, 0.78 \%$, and $0.39 \%$, respectively), then tube 10 was given $\mathrm{K}(+)$ label, which was a positive control. Tube 10 contained the bacterial suspension, which was equivalent to McFarland 0.5 turbidity standard. Tube 11 was labeled with $\mathrm{K}(-)$, which was a negative control. This tube contained okra fruit extract with a concentration of $100 \%$. The tube 1 was filled with $4 \mathrm{~mL}$ concentration of $100 \%$ okra fruit extract. The tubes $2-9$ were filled with $2 \mathrm{~mL}$ of BHIB liquid media. Two milliliter of solution from the tube 1 was put in tube 2 . It was mixed until homogeneous, so that the concentration of $50 \%$ was obtained. The same thing was carried out up to tube 9 until all extract concentrations were obtained with a ratio of $1: 2(\mathrm{wt} / \mathrm{vol})$. To test turbidity, bacterial suspension media were taken, which had been equalized with McFarland 0.5 turbidity standard of $0.1 \mathrm{~mL}$ and put into test tubes in 1-9 labels (concentrations of $100 \%$, $50 \%, 25 \%, 12.5 \%, 6.25 \%, 3.125 \%, 1.563 \%, 0.78 \%$, and $0.39 \%$, respectively). Then, all the tubes that were put in an airtight anaerobic container were then incubated at $37^{\circ} \mathrm{C}$ for $1 \times 24 \mathrm{~h}$. After one incubation, turbidity was observed. If the turbidity of the tube was still equivalent or more turbid than the positive control $(\mathrm{K}+)$ tube containing the bacterial suspension McFarland 0.5, it meant that bacteria can still thrive. However, when the solution in the tube appeared to be clearer than the $\mathrm{K}(+)$ tube, it meant that the growth of bacteria began to be inhibited. This was what showed the minimum inhibition concentration (MIC). After observing turbidity, a total plate count (TPC) test was conducted to determine bacteriostatic and bacteriocide properties. The TPC test was carried out on Mueller Hinton agar media containing concentrations of extracts from tubes that looked the clearest. Furthermore, each petri dish was incubated at $37^{\circ} \mathrm{C}$ for $1 \times 24 \mathrm{~h}$. The number of colonies was then counted.

\section{Statistical analysis}

The data obtained were the number of bacterial colonies measured in CFU. Data were then tabulated and analyzed using the Statistical Package for the Social Sciences (SPSS) software, version 20 (IBM, New York).

The data distribution was carried out with the KolmogorovSmirnov test to determine whether the data could be normally distributed. To identify whether the collected data were homogeneous, a variance homogeneity test was performed using the Levene test with $\alpha>0.05$. Furthermore, the parametric test using the analysis of variance (ANOVA) 
was used to identify the significance of differences in the number of bacterial colonies between the study groups. All analyses were tested at the significance level of 0.05 .

\section{RESULTS}

From the three treatments, the number of $A a$ bacterial colonies from the positive control tube TPC test, negative control, tube 4 , tube 5 , tube 6 , and tube 7 were obtained as shown in Figures 1 and 2.

Table 1 shows that the MIC of okra fruit extract on $A a$ bacteria is on the sixth tube at a concentration of $3.125 \%$, and the minimal bactericidal concentration (MBC) is on the fifth tube at a concentration of $6.25 \%$.

Data obtained showed that they were normally distributed based on the Kolmogorov-Smirnov test normality test, then Levene homogeneity analysis test showed that data were homogeneous with $P=0.215(>0.05)$ [Table 2]. The results of the research data were analyzed using one-way ANOVA statistical test [Table 2], the results showed that there was a significant difference $(P=0.000)$ between the control group compared to the treatment group giving okra fruit extract (Abelmoschus esculentus). While the statistical analysis using the Tukey HSD test showed that a significant difference occurred between the control group and the treatment group in the administration of okra ( $A$. esculentus) fruit extracts at concentrations of $3.125 \%$, and $1.565 \%$. This means that there are significant differences in inhibiting or killing the $A a$ bacteria [Table 3].

\section{Discussion}

On the basis on the results of data analysis from the oneway ANOVA test in Table 1, the $P$ value was found to be 0.000 , indicating that if $P<0.05$, it means that there is a significant difference between the control group and the treatment group. The results obtained indicate that the administration of natural okra (A. esculentus) extracts is effective in inhibiting or killing the $A a$ bacteria, which are predominant bacteria causing AP.

Figure 3 is the observation of $11 A a$ bacteria tubes containing okra fruit extracts showing that MIC is in tube number 6 with okra fruit extract concentration of $3.125 \%$ which is marked by a slight turbidity in the tube and which shows MBC in tube number 5 with extract concentration okra fruit of $6.25 \%$ which is marked by the absence of turbidity in the tube. The next step is to find out the presence or absence of bacterial growth in each tube, then the scraping method of the 11 tubes of the serial results of the A. actinomycetemcomitans bacterial dilution on the media so that Mueller Hinton uses the streaking method.
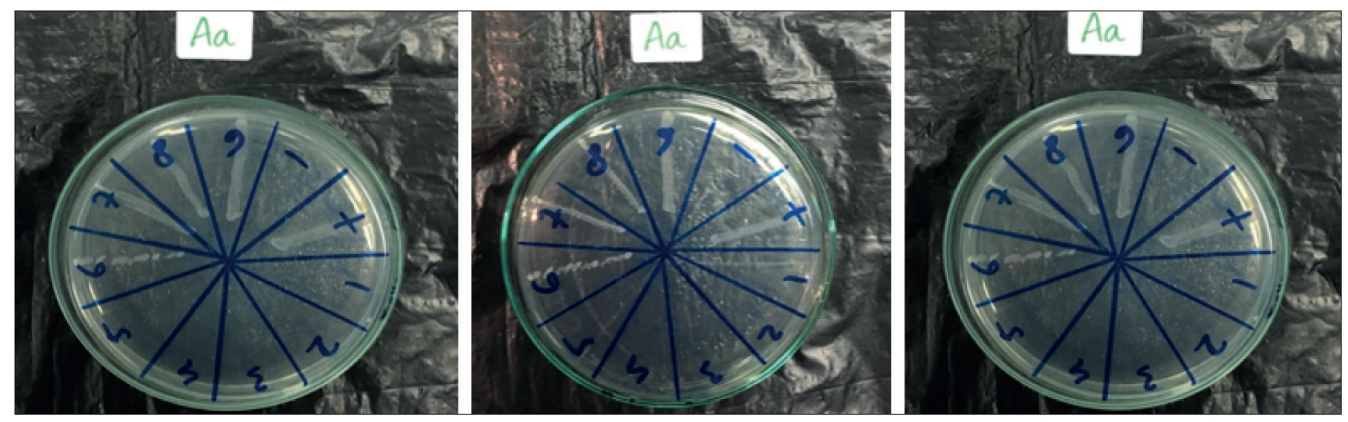

Figure 1: Results of scratches from 11 test tubes that showed the presence of Aggregatibacter actinomycetemcomitans bacteria growth in Mueller Hinton media from three replications
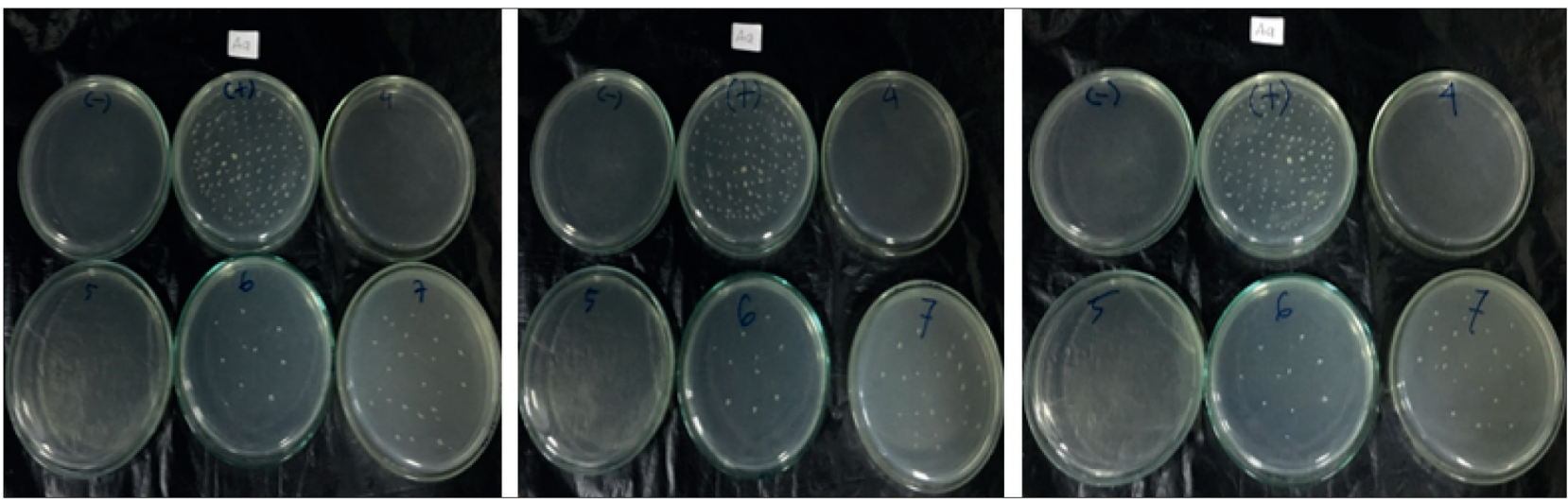

Figure 2: Total plate count test on Mueller Hinton media from positive control tube, negative control tube, number 4 tube, number 5 tube, number 6 tube, and number 7 tube from three replications 
From previous studies it was said that phytochemical ingredients such as quercetin have antimicrobial activity against gram-positive and gram-negative bacteria. ${ }^{[9]}$

The effectiveness of the extract of okra fruit (A. esculentus) is caused by its content in the form of secondary metabolite components such as flavonoids, alkaloids, terpenoids, and quercetin. ${ }^{[6]}$

The antibacterial effect resulting from the extraction of okra against $A a$ is due to the presence of active substances that are soluble and contained in $70 \%$ ethanol solvent, which is a flavonoid and is a polar compound, which is generally soluble in polar solvents, namely phenols and quercetin. ${ }^{[10]}$ During the extraction process of okra fruit (Abelmoschus esculentus) ethanol solvent is used because ethanol is a polar solvent that has a hydroxyl group $(\mathrm{OH})$ that participates in the formation of hydrogen bonds which is the cause of the liquid is difficult to evaporate when compared with other organic compounds. ${ }^{[1]}$

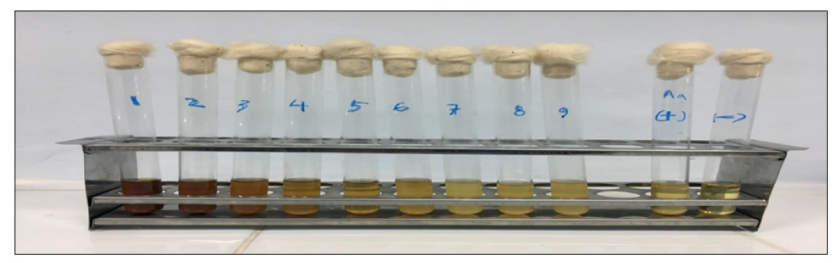

Figure 3: Results of serial dilution of okra fruit extract on Aggregatibacter actinomycetemcomitans bacteria. The first tube contains 100\% okra fruit extract. Tube 2 contains $50 \%$ okra extract concentration. Tube 3 contains $25 \%$ okra extract concentration. Tube 4 contains $12.5 \%$ okra extract concentration. Tube 5 contains $6.25 \%$ okra extract concentration. Tube 6 contains $3.125 \%$ okra extract concentration. Tube 7 contains $1.563 \%$ okra extract concentration. Tube 8 contains $0.78 \%$ okra extract concentration. Tube 9 contains $0.39 \%$ okra extract concentration. The tube $(+)$ is a positive control. Tube $(-)$ is a negative control
Quercetin has many biological properties such as antioxidants, nerve protection, antiviral, anticancer, cardiovascular, antimicrobial, anti-inflammatory, and anti-obesity. ${ }^{[12]}$ It has been widely used in herbal medicine as traditional medicine for hundreds of years. ${ }^{[13]}$

The antibacterial potential of quercetin against the $A a$ bacteria is caused because quercetin has the ability to react to form complex components with metals such as $\mathrm{Ag}, \mathrm{Au}$, and $\mathrm{Fe}^{[12]}$ This is one reason that quercetin has potential antimicrobial activity. ${ }^{[14]}$ Antibacterial activities of quercetin are mechanism against the cytoplasmic membrane of the bacteria, which is damaged through the perforation action of the quercetin. The inhibition of both energy metabolism and the synthesis of nucleic acids is another mechanism. ${ }^{[15]}$ Flavonoids as antimicrobials, which are one of the active ingredients of okra fruit extract, have three mechanisms of action in killing microbes, the first possibility is to inhibit the synthesis of nucleic acids, the second is to inhibit the function of cell membranes, and the third is to inhibit the metabolism in bacterial cells, from all three aspects, flavonoids can cause damage to permeability in bacterial cell walls, microsomes, and lysosomes as a result of interactions between flavonoids

\begin{tabular}{|c|c|c|c|c|}
\hline \multirow[t]{2}{*}{ Group } & \multirow{2}{*}{$\frac{N}{1}$} & \multicolumn{3}{|c|}{ Subset for alpha $=0.05$} \\
\hline & & 2 & 3 & 1 \\
\hline $\begin{array}{l}\text { Concentration } \\
\text { of } 3.125 \%\end{array}$ & 3 & 13.0000 & & \\
\hline $\begin{array}{l}\text { Concentration } \\
\text { of } 1.565 \%\end{array}$ & 3 & & 26.3333 & \\
\hline Positive control & 3 & & & 120.6667 \\
\hline Sig. & & 1.000 & 1.000 & 1.000 \\
\hline
\end{tabular}

Table 1: Results of the number of Aggregatibacter actinomycetemcomitans bacterial colonies

\begin{tabular}{lcccc}
\hline Tube & Concentration of okra fruit extract & \multicolumn{3}{c}{ Number of Aa bacterial colonies (CFU/mL) } \\
\cline { 3 - 5 } & & Treatment 1 & Treatment 2 & Treatment 3 \\
\hline 4 & $12.5 \%$ & - & - & - \\
5 & $6.25 \%$ & - & - & - \\
6 & $3.125 \%$ & 11 & 15 & 13 \\
7 & $1.565 \%$ & 25 & 28 & 26 \\
$(+)$ & $100 \%+$ bacteria & 116 & 126 & 120 \\
$(-)$ & $100 \%$ without bacteria & - & - & -
\end{tabular}

Table 1 shows that the minimal inhibitory concentration of okra fruit extract on Aggregatibacter actinomycetemcomitans bacteria is on the sixth tube at a concentration of $3.125 \%$ and the minimal bactericidal concentration is on the fifth tube at a concentration of $6.25 \%$

Table 2: One-way analysis of variance test for bacterial Aggregatibacter actinomycetemcomitans between groups

\begin{tabular}{lccccc} 
& Sum of squares & $\boldsymbol{d f}$ & Mean square & $\boldsymbol{F}$ & Sig. \\
\hline Between groups & $20,668.667$ & 2 & $10,334.333$ & 979.042 & \\
Within groups & 63.333 & 6 & 10.556 & \\
Total & $20,732.000$ & 8 & & \\
\hline
\end{tabular}

*Significant 
and bacterial deoxyribonucleic acid. The mechanism of action of flavonoids inhibits the function of cell membranes to form complex compounds with extracellular proteins that can damage bacterial cell membranes and is followed by the release of intracellular compounds. ${ }^{[16]}$ Flavonoids have the ability to inhibit cell membrane function by interfering with the permeability of cell membranes and inhibiting the binding of enzymes, such as ATPase and phospholipase. The correlation between antibacterial activity and membrane disorders supports the theory that flavonoids can show antibacterial activity by reducing the fluidity of bacterial cell membranes.

Therefore, the results showed that there was a significant decrease in the number of Aa colonies in the administration of okra fruit extract with a concentration of $3.125 \%$, while in the administration with a concentration of $6.25 \%$ there was no growth of $A a$ bacteria. On the basis of the role of the flavonoid content of okra fruit extract as aforementioned, okra fruit extract had the power to kill $A a$ bacteria, which was shown by the MIC in the administration of $3.125 \%$, whereas the $\mathrm{MBC}$ was at $6.25 \%$.

The okra fruit extract effectively kills the $A a$ bacteria, which is the bacterium that causes $\mathrm{AP}$ as indicated by MIC at a concentration of $3.125 \%$ and $\mathrm{MBC}$ at a concentration of $6.25 \%$.

\section{Acknowledgement}

The authors would like to acknowledge the Research Centre Faculty of Dental Medicine Universitas Airlangga.

\section{Source of Funding}

The authors would like to thank Directorate of Research and Community Services of Directorate General of Research and Development Strengthening from Ministry of Research, Technology and Higher Education of the Republic of Indonesia for the grant funding provided for this research.

\section{Conflicts of interest}

There are no conflicts of interest.

\section{Authors contributions}

Muhammad Luthfi: Study conception, study design, intelectual content, literature research, data acquisition, data analysis, manuscript review, guarantor. Yuliati: data interpretation, Statistical analysis, manuscript preparation, manuscript editing. Aqsa Sjuhada Oki: Study concept, clinical studies, experimental studies. Agung Sosiawan: Data analysis, manuscript review. Bella P Cida: Study concept, clinical studies, experimental studies.

\section{Ethical policy and Institutional Review board statement}

Ethical clearance test at Universitas Airlangga, Faculty of Dental Medicine was done with Health Research Ethical Clearance Commission number of 112/HRECC. FODM/ $\mathrm{VII} / 2018$.

\section{Data availability statement}

Dataset can be made available after embargo period due to commercial restrictions.

\section{List of Abbreviations}

MIC: Minimal inhibitory concentration, MB: Minimal bactericidal, CFU: Colony forming units, AP: Aggressive periodontitis, BHIB: Brain heart infusion broth, TPC: Total plate count, LPS: Lipopolysaccharides, ATCC: American Type Culture Collection

\section{References}

1. Quamilla N. Stress and periodontitis. J Syiah Kuala Dent Soc 2014;1:162-3.

2. Aristizorresbal JF, Martínez R. Tratamiento ortodóncico y periodontal combinado en pacientes con periodontitis agresiva tratada y controlada. Rev Fac Odontol Univ Antioq 2014;26:180-204.

3. Faveri M, Figueiredo LC, Duarte PM, Mestnik MJ, Mayer MP, Feres M. Microbiological profile of untreated subjects with localized aggressive periodontitis. J Clin Periodontol 2009;36:739-49.

4. Dahlen G, Basic A, Bylund J. Importance of virulence factors for the persistence of oral bacteria in the inflamed gingival crevice and in the pathogenesis of periodontal disease. J Clin Med 2019;8:1-19.

5. Shahat AA, Mahmoud EA, Al-Mishari AA, Alsaid MS. Antimicrobial activities of some Saudi Arabian herbal plants. Afr J Tradit Complement Altern Med 2017;14:161-5.

6. Lisnawati N, Handayani IA, Fajrianti N. Analysis of flavonoids from ethanol extract $96 \%$ of the skin of red okra fruit (Abelmoschusesceluntus L. Moench) by thin layer chromatography and spectrophotometry UV-VIS. J Ilm Ibnu Sina 2016;1:105-12.

7. Wijaya V, Maharani ES, Gunawan HA, Puspitawati R. The efficacy of an infusion of binahong leaves (Anredera cordifolia (ten.) steenis) against wild strain black-pigmented bacteria. Int J Appl Pharm 2017;9:28-31.

8. Soelama HJJ, Kepel BJ, Siagian KV. Minimum inhibitory concentration (MIC) test of seaweed extract (Eucheuma cottonii) as an antibacterial against Streptococcus mutans. J e-GiGi (eG) 2015;3:375-6.

9. Nakamura K, Ishiyama K, Sheng H, Ikai H, Kanno T, Niwano Y. Bactericidal activity and mechanism of photoirradiated polyphenols against gram-positive and -negative bacteria. J Agric Food Chem 2015;63:7707-13.

10. Yulianingtyas A, Kusmartono B. Optimization of solvent volume and maceration time on extraction of flavonoids from Averrhoa bilimbi leaves. J Chem Eng 2016;10:58-64.

11. Jayus J, Suwasono S, Wijayanti E. Production of bioethanol by SHF and SSF using Aspergillus niger, Trichoderma viride, and new aule instant dry yeast on cassava peel media. J Agrotechnol 2017;11:61-8.

12. Daglia M. Polyphenols as antimicrobial agents. Curr Opin Biotechnol 2012;23:174-81.

13. Shu Y, Liu Y, Li L, Feng J, Lou B, Zhou X, et al. Antibacterial activity of quercetin on oral infectious pathogens. Afr J Microbiol Res 2011;5:5358-61.

14. Ahmad A, Kaleem M, Ahmed Z, Shafiq H. Therapeutic potential of flavonoids and their mechanism of action against microbial and viral infections - A review. Food Res Int 2015;77:221-35.

15. Putra AH, Corvianindya Y, Wahyukundar MA. Antibacterial activity of etanol extract of white frangipani leaf (Plumeria acuminata) against the growth of Streptococcus mutans. e-Jurnal Pustaka Kesehatan 2017;5:449-53.

16. Kumar S, Pandey AK. Phenolic content, reducing power and membrane protective activities of Solanum xanthocarpum root extracts. Vegetos 2013;26:301-7. 